\title{
CONTRIBUTION TO THE BRYOFLORA OF AUSTRALIA, V. COLURA STREIMANNII SP. NOV. FROM QUEENSLAND
}

\author{
TAMÁs Pócs
}

\begin{abstract}
A new species of Colura (Dumort.) Dumort., was collected in the Cape Tribulation area of Queensland, in the mangrove forests of Daintree National Park. It is a member of subgenus Colura, section Harmophyllum Grolle, and differs from the superficially similar Colura pulcherrima Ast and C. queenslandica B. M. Thiers (both belong to another subgenus or section) by its easily detachable valve or by its acutely papillose lobule surface. Cheilolejeunea occlusa (Herz.) Kodama \& Kitagawa occurs in the same habitat. This is a new record for Australia.
\end{abstract}

Key words: Australia, Cheilolejeunea, Colura, endemics, mangrove forest, Heinar Streimann, Queensland

Tamás Pócs, Botanical Department, Institute of Biology, Eszterházy College,Eger, Pf. 43, H-3301, Hungary; e-mail: colura@upcmail.hu

\section{INTRODUCTION}

The fifth publication of this series describes a new species of Colura (Dumort.) Dumort., dedicated to the late Heinar Streimann, former botanist of the Australian National Herbarium, Centre for Plant Biodiversity Research (now the Centre for Australian National Biodiversity Research), Canberra. Streimann organized a $9000 \mathrm{~km}$ long collecting trip in eastern Australia for me, sponsored by the Australian Biological Resources Study Participatory Programme. With his help I collected thousands of Frullania specimens for the Flora of Australia Project, along with many other liverworts, one set of which is deposited in CANB and the other in the Eger Herbarium (EGR). The four previous publications described different taxa new to Australia or to science (Pócs \& Streimann 2006; Pócs 2006; Pócs \& Cairns 2008; Pócs et al. 2012). There was a mistake, as two of them were numbered III, so this is the fifth contribution.

On 27 August 1999 we visited the Daintree National Park south of Cape Tribulation, along the 'Botanical Circuit' near Noah Creek. In the part farther from the creek we found a temporarily waterlogged lowland rainforest rich in prop-rooted and cauliflorous trees and palms (mostly Licuala sp.), and in the inner part, closer to the creek and to the coast, a tall $(-12 \mathrm{~m})$ mangrove forest dominated by
Rhizophora and Xylocarpus (Meliaceae) trees. Both forest types proved to be rich in epiphytes, including bryophytes. From these localities we have already published Colura corynophora (Nees) Trevis. and Lepidolejeunea integristipula (J. B. Jack \& Steph.) R. M. Schust. as new to Australia and Cheilolejeunea streimannii Pócs \& T. N. Ninh as new to science (Pócs \& Ninh 2005; Pócs \& Streimann 2006), along with many other interesting liverworts. In the mangrove forest we noticed a few shoots of a whitish Colura species on the pale brown peeling bark of Xylocarpus cf. granatum J. König, embedded in a dense weft of Metalejeunea cucullata (Reinw. et al.) Grolle, Cheilolejeunea occlusa (Herzog) Kodama \& Kitagawa (a new record for Australia) and a number of Frullania species. The Colura species proved to be new to science.

DESCRIPTION OF THE NEW SPECIES AND DISCUSSION

Colura streimannii Pócs, sp. nov. (Subg. Colura, sect. Harmophyllum Grolle, J. Hattori Bot. Lab. 28: 44. 1965) Figs 2-4 \& 6-14

Type: AUSTRALIA, QueEnSLAND: Daintree National Park S of Cape Tribulation, $38 \mathrm{~km} \mathrm{NNE}$ of 

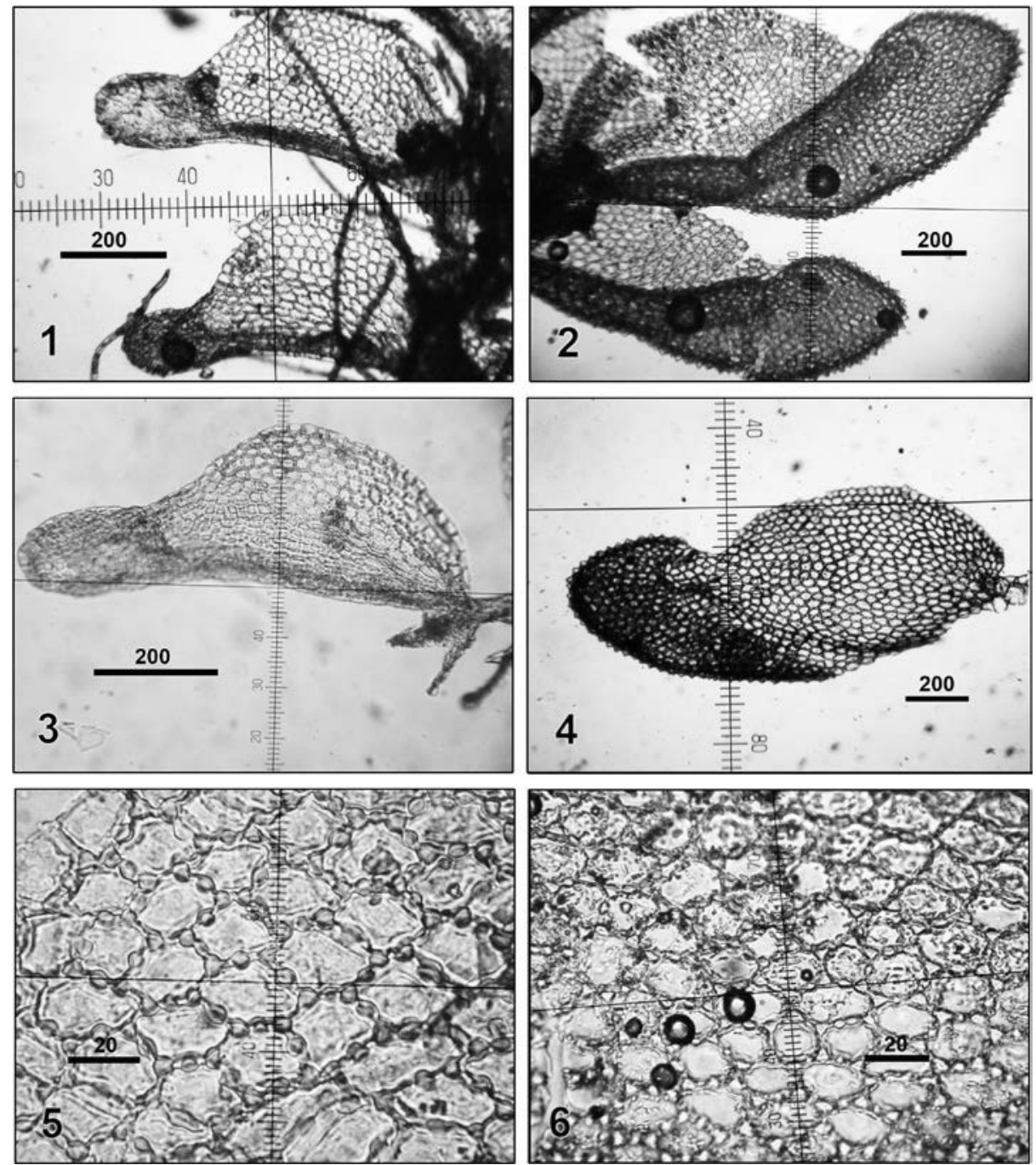

Figs 1-6. 1, 3, 5 - Colura queenslandica B. M. Thiers, Queensland, from the type locality, Bellenden Ker, $1550 \mathrm{~m}$, epiphyllous, Pócs \& Streimann 9981/AL (CANB, EGR). 2, 4, 6 - Colura streimannii Pócs, sp. nov. Microphotos made from the type. $1 \& 2$ - habit, ventral view, $3 \& 4$ - leaves, $5 \& 6$ - median lobe cells. Scale bars in $\mu \mathrm{m}$.

Mossmann. 'Botanical Circuit' along Noah Creek, $16^{\circ} 08.8^{\prime} \mathrm{S}, 145^{\circ} 26.7^{\prime} \mathrm{E}$, at $1-2 \mathrm{~m}$ a.s.l. Mangrove forest with Rhizophora and with Xylocarpus (Meliaceae), rich in epiphytes. On peeling bark of Xylocarpus cf. granatum J. König. Collected by Pócs \& Streimann 9990/C (HOLOTYPE: EGR; ISOTYPE: CANB).

Greenish white, creeping shoots of $6-9 \mathrm{~mm}$ length and 1.5-2.0 mm width, not adherent to the substrate. Stem up to $60 \mu \mathrm{m}$ in diameter, sparsely branching. Leaves contiguous, often erect from substrate, 1400-1600 $\mu \mathrm{m}$ long, diverging from stem at $30-80^{\circ}$. Lobes $800-1200 \mu \mathrm{m}$ long and $500-750 \mu \mathrm{m}$ wide, in dry state often inrolled. Median lobe cells $14-24 \times 10-14 \mu \mathrm{m}$, with bulging trigones and intermediate thickenings. Lobules 1200-1600 $\mu \mathrm{m}$ long and 400-500 $\mu \mathrm{m}$ wide, gradually broadening in an inflated conical sac with rounded apex. Lobule cells more or less isodiametric, $15 \mu \mathrm{m}$ in diameter, each tipped on its outer side with an 8-12 $\mu \mathrm{m}$ high, acute, conical papilla, 

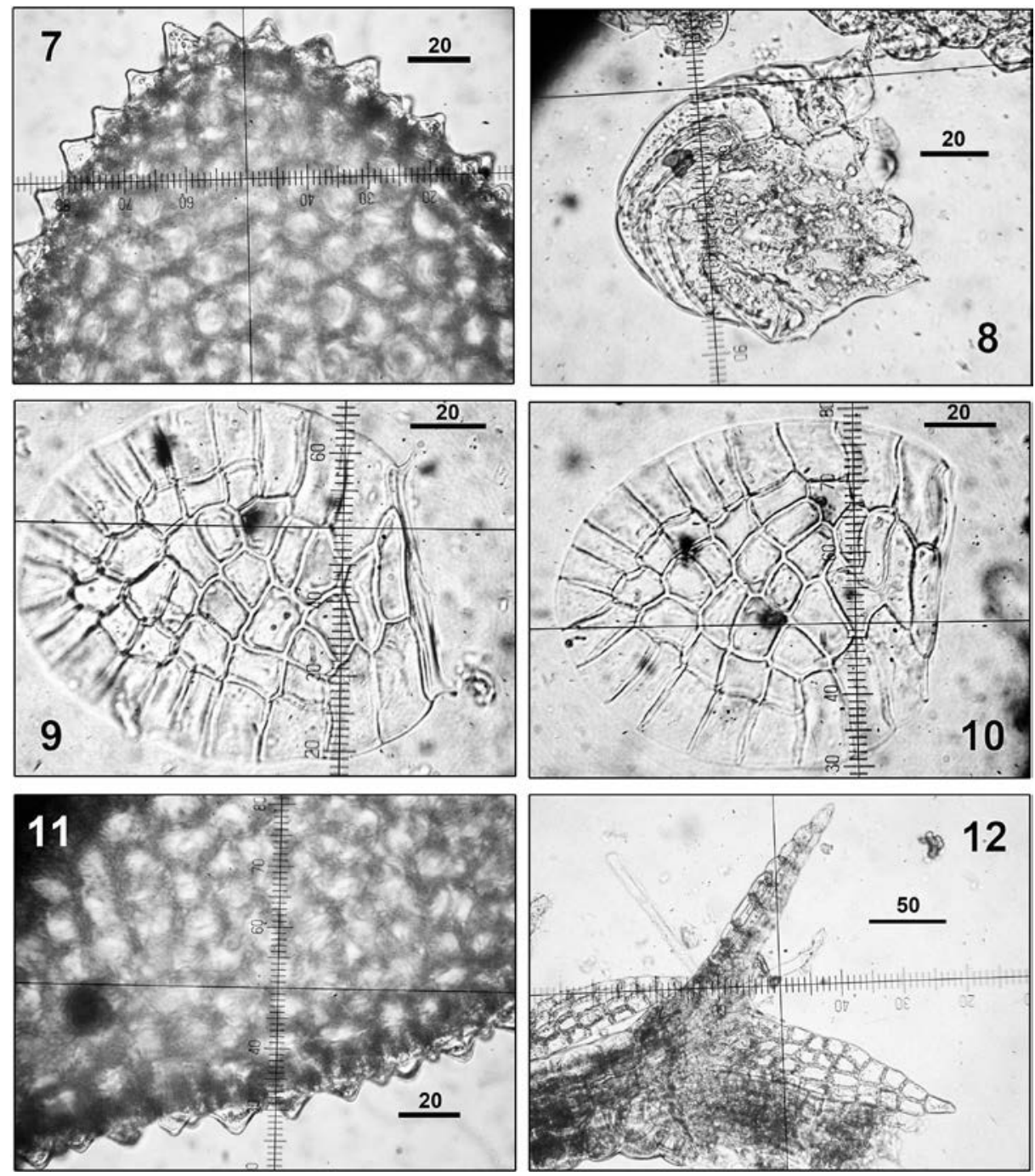

Figs 7-12. Colura streimannii Pócs, sp. nov. Microphotos made from the type. 7 - apical cells of lobule, 8 - frame, 9 \& $10-$ valves, 11 - median lobule edge, 12 - underleaves. Scale bars in $\mu \mathrm{m}$.

clearly visible even with a handlens. Frame (arch of emergent lobe cells adherent to the closed valve) consists of $4-5$ bent elongate cells. Valve easily detachable, with a hinge and with one basal-median cell. Valve composed of 20-21 hyaline marginal and 24-26 median cells. Underleaves asymmetric $\mathrm{V}$ shaped, with acute lobes 4 cells wide at their base. Rhizoids sparse, hyaline. Sterile.

ETymology. The species is named to commemorate Heinar Streimann (1938-2001), eminent botanist, collector of a very large number of bryophytes in Australia, New Guinea, New Zealand, Vanuatu and other areas of Australasia. He was the co-collector of this new species.

The new species bears a superficial resemblance to Colura pulcherrima Ast due to its leaf shape and papillose surface and to some extent to $C$. queenslandica Thiers by its leaf shape, but well differs from the first by its much larger size, the different shape of lobule papillae and above all 

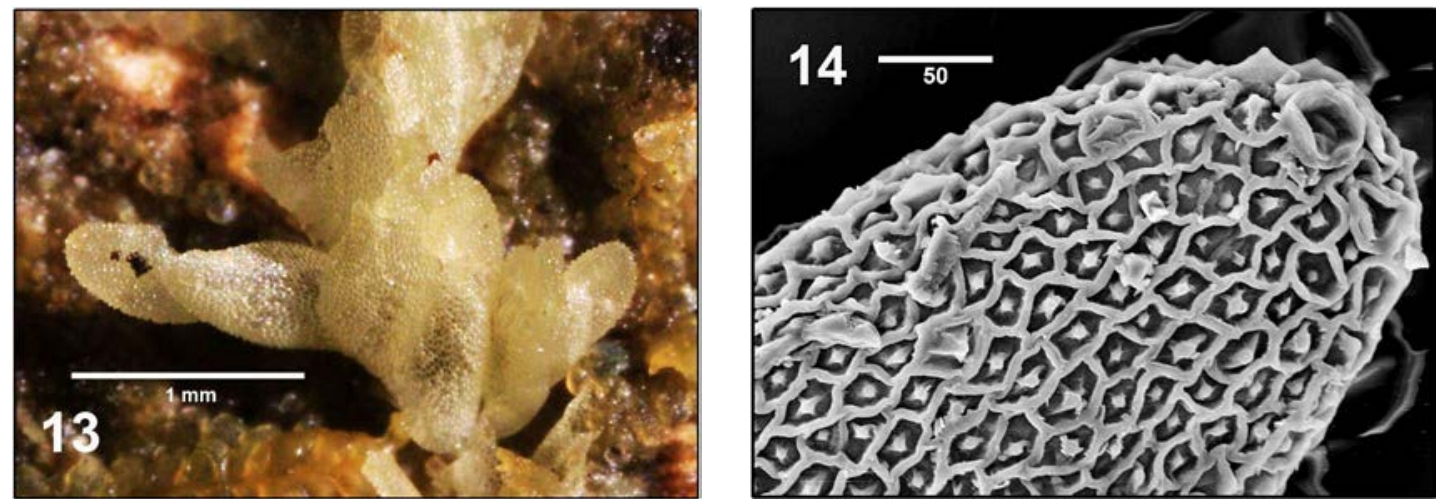

Figs 13-14. Colura streimannii Pócs, sp. nov. Macrophoto and SEM images made from the type. 13 - habit. 14 - lobule apex in dry state (scale bar in $\mu \mathrm{m}$ ).

by its valve always composed of only one quadrangular basal cell and its much larger number of marginal and median cells; from the second it differs by its acutely papillose lobule surface and detachable valve.

Knowledge of Australian Colura started with the classic work of Jovet-Ast (1953, 1954), who in describing C. bisvoluta Herz. \& Ast from Sumatra mentioned its occurrence also in Queensland, collected by Brass in 1948. Also described was C. australiensis Ast from Mt. Bellenden Ker collected by Hill in 1873 . When Thiers (1987) made a preliminary account of Colura in Australia, she already enumerated and described 10 species; one of them, C. queenslandica B. Thiers, was new to science. McCarthy (2003) mentions 11 species and a variety in his checklist. More recently, Pócs and Streimann (2006) added three more species, and so, together with C. streimannii, 15 species are known from the continent. If we compare them with the 25 species known from New Guinea and from the neighboring islands (Pócs 2013), it seems to be a modest number. However, as 13 of the Colura species in Australia are restricted to the narrow eastern wet tropical belt of Queensland and two to the southern wet temperate zone of the states of Victoria and Tasmania, it is a substantial level of species diversity.

Concerning the phytogeographic composition of the Australian Colura flora, we can consider three species to be QUEENSLAND ENDEMICS: C. queenslandica B. Thiers, C. simplicior Ast and
C. streimannii Pócs. Four species are AustralASIAN taxa: C. australiensis Ast (Australia and Solomon Islands, Pócs 2013), C. crispiloba Ast (Australia and Fiji, Pócs \& Eggers 2007), C. pulcherrima Ast var. bartlettii Ast (Southern Australia and New Zealand, Jovet-Ast 1953, McCarthy 2003) and C. saccophylla E. A. Hodgs. \& Herzog (Southern Australia and New Zealand, Jovet-Ast 1953, McCarthy 2003). Eight are InDOMALESIANPACIFIC SPECIES: C. acroloba (Mont.) Ast., C. apiculata (Schiffn.) Steph., C. ari (Steph.) Steph., C. bisvoluta Herzog \& Ast, C. conica (Sande Lac.) K. I. Goebel, C. herzogii Ast, C. leratii (Steph.) Steph. and C. ornata K. I. Goebel. Finally, one species, C. pulcherrima Ast has an AMPHIPACIFIC, SOUTHERN TEMPERATE distribution.

AcKNOWLEDGEMENTs. I am greatly indebted to the late Heinar Streimann, who took me on a $9000 \mathrm{~km}$ long journey in the wetter parts of Australia. I acknowledge with thanks the support of the Australian Biological Resources Study Participatory Programme for sponsoring his collecting trip. I thank the Hungarian Natural History Museum (BP) for the use of its Hitachi S-2055 N scanning electron microscope and Dr. Krisztina Buczkó for help with its operation, and Dr. D. Christine Cargill (CANB) and an anonymous reviewer for their valuable comments.

\section{REFERENCES}

Jovet-Ast S. 1953. Le genre Colura, Hépatiques, Lejeuneacées, Diplasiae. Rev. Bryol. Lichénol. 22: 206-312. 
Jovet-Ast S. 1954. Le genre Colura, Hépatiques, Lejeuneacées, Diplasiae (supplement). Rev. Bryol. Lichénol. 23: $1-22$.

McCARThy P. M. 2003. Catalogue of Australian liverworts and hornworts. Flora of Australia Supplementary Series 21. Australian Biological Resources Study, Canberra.

Pócs T. 2006. Contribution to the bryoflora of Australia, II. On the Australasian "Tuyamaelloideae" (Lejeuneaceae), with the description of Austrolejeuna occidentalis. J. Hattori Bot. Lab. 99: 185-195.

Pócs T. 2013. The genus Colura (Lejeuneaceae) in New Guinea and in the neighboring areas. Chenia 11: 12-38.

Pócs T., Brown E. A., Cairns A., Cargill D. C. \& Pócs S. 2012. Contribution to the bryoflora of Australia III. The genus Nowellia Mitt. (Cephaloziaceae, Jungermanniopsida). Acta Biologica Plantarum Agriensis 2: 21-26.
Pócs T. \& CAIRns A. 2008. Contributions to the Bryoflora of Australia, III. The genus Jubula Dumort., with the description of $J$. hutchinsiae Hook. subsp. nov. australiae (Jubulaceae, Jungermanniopsida). Nova Hedwigia 86(1-2): 231-236.

Pócs T. \& EgGers J. 2007. Bryophytes from the Fiji Islands, II. An account of the genus Colura, with the description of C. vitiensis sp. nov. Polish Bot. J. 52(2): 81-92.

Pócs T. \& Streimann H. 2006. Contributions to the bryoflora of Australia, I. Tropical Bryology 27: 19-24.

Pócs T. \& Ninh T. 2005. Contribution to the bryoflora of Vietnam, VI. On the liverwort flora of Vu Quang Nature Reserve. Acta Bot. Hung. 47(1-2): 151-171.

Thiers B. M. 1987. A preliminary account of Colura (Hepaticae, Lejeuneaceae) in Australia. Brittonia 39(2): $175-179$.

Received 1 March 2015 